\title{
DUMAIS, Monique. Femmes et mondialisation. Montréal: Médiaspaul, 2009.
}

\section{Mulheres e Mundialização}

João Batista Libanio*

O livro é escrito na perspectiva da teologia feminista. A autora é religiosa ursulina, professora emérita da Universidade do Quebec, Canadá. O tema central se expressa bem no título: mulheres e mundialização. Distinguindo mundialização de globalização - a segunda se refere ao campo econômico em escala planetária, enquanto a primeira diz respeito a um fenômeno cultural mais abrangente -, a autora esclarece não ter sentido falar de globalização dos direitos humanos, e sim de mundialização. Existe uma mundialização no sentido de aproximação e interdependência dos povos como processo multissecular, que se acelerou a partir das grandes descobertas, das conquistas coloniais e do progresso nas comunicações a partir dos séculos XV e XVI. Sem desconhecer o aspecto econômico da mundialização, a autora trabalha, sobretudo, a questão cultural em sua amplitude, com especial referência ao impacto que ela causa sobre a mulher. "Os efeitos da mundialização não afetam indiferentemente os dois sexos.” E nos aspectos negativos, a mulher acaba sendo a maior vítima por causa de longa tradição machista.

Dois traços fundamentais caracterizam a obra. A autora revela excelente grau de informação, o que se evidencia nas inúmeras citações, especialmente de mulheres envolvidas teórica e praticamente com a mundialização. Tem-se uma ideia da ampla presença feminina e das crescentes ondas de pessoas conscientes da gravidade da atual problemática em torno do tema central. Uma segunda característica casaria bem com a atitude de sabedoria. Não se trata tanto de uma obra de elaboração teórica sobre os problemas, mas de enorme sensibilidade pelas questões abordadas, unida a um senso de

\footnotetext{
*Doutor em Teologia (Gregoriana-Roma) e professor da Faculdade Jesuíta de Filosofia e Teologia (Faje). Email: secteologia@faculdadejesuita.edu.br
} 
humanidade e sabedoria humana. Uma obra que suscita a reflexão, a discussão e se presta a conscientizar as pessoas sobre a mundialização e suas implicações.

O toque teológico-religioso marca o texto, alimentado fundamentalmente pelo senso ético em face dos problemas da atualidade. O leitor se adentra numa série de iniciativas do Canadá, em especial de Quebec, e do mundo todo referentes à luta contra as consequências negativas da globalização e da mundialização. Toca-se em ampla gama de temas. Depois de proceder a uma rápida caracterização da globalização econômica na introdução, a autora alude à experiência do Quebec de ter criado, em 2002, um observatório da mundialização para conscientizar as pessoas de todos os seus aspectos e para oferecer à nação quebequense informações confiáveis para se posicionar lucidamente em relação a ela.

O texto se detém em dados sobre os movimentos de conscientização, sobre o Fórum Social Mundial iniciado em Porto Alegre, sobre a Associação para a Taxação das Transações Financeiras para a Ajuda dos Cidadãos (Attac) na linha da Taxa Tobin, sobre a Marcha Mundial das Mulheres, sobre a luta por uma ética solidária, sobre o ecofeminismo, sobre o problema do meio ambiente, etc. Há muitos testemunhos de mulheres lutadoras do Terceiro Mundo, tais como Vandana Shiva e Arundhati Royas (Índia), Shirin Ebadi (Irã), Satako (Mali), Benazir Bhutto (Paquistão).

A autora discorre também sobre o tráfico de mulheres (do $3^{\circ}$ Mundo para $01^{\circ}$ ), seja para se ocupar de trabalhos mais pesados, seja para fins de exploração sexual. Denuncia ainda a generalizada desigualdade de salário entre mulheres e homens, constatando uma verdadeira feminização da pobreza.

O livro tem páginas que apontam caminhos éticos ante a exploração das mulheres, dos pobres e da natureza. O itinerário ético parte da tomada de consciência da dominação criada pelo mundo da globalização e da mundialização. Um primeiro caminho apontado é a solicitude máxima em relação aos alimentos, à fabricação de armas, à destruição do meio ambiente - campos em que a atuação de transnacionais alcança requintes de perversidade. A autora sinaliza também movimentos de protesto. Reivindica justiça para o mundo do trabalho, no qual a mulher mais que ninguém é explorada. Sob a epígrafe de sabedoria, toca quatro temas fundamentais: educação, cidadania, política e economia - campos em que a mulher também é vítima de discriminação. Fecha o livro apelando para os valores da solidariedade, da defesa dos direitos fundamentais da mulher, do seu reconhecimento como 
pessoa humana. Numa palavra, ela propugna uma mundialização humanizante, considerando, de modo especial, a situação da mulher.

O livro cumpre a função de conscientização e de apelo ético. Não se trata de mera proposta idealista e utópica, pois aponta para o que já está sendo feito no mundo. Vem, portanto, reforçar um projeto em andamento. 